Journal of Economics, Finance and Accounting Studies (JEFAS)

ISSN: $2709-0809$

DOI: $10.32996 /$ jefas

Journal Homepage: www.al-kindipublisher.com/index.php/jefas

\title{
The Economic, Social, and Environmental Impacts of Generalization of Solar Water Heaters
}

\author{
Faycel Tazigh \\ Hantos Elemér Business and Regional Sciences Doctoral School, University of Miskolc Hungary \\ $\square$ Corresponding Author: Faycel Tazigh, E-mail: fayceltazigh@gmail.com
}

\begin{tabular}{|c|c|}
\hline ARTICLE INFORMATION & ABSTRACT \\
\hline Received: 11 October 2021 & \multirow{6}{*}{$\begin{array}{l}\text { This paper aims to quantify the three main aspects of sustainable development, the } \\
\text { economic, social, and environmental impacts of the generalization of solar water } \\
\text { heaters in Marrakech. In order to conduct this Impact assessment study, we used both } \\
\text { quantitative and qualitative analysis. The impact assessment analysis has been done } \\
\text { on three different levels: households, Tourism, and private and public institutions. The } \\
\text { generalization of SWH at the scale of the city of Marrakech will be in this perspective } \\
\text { the origin of a profit today neglected. The resulting impact, both economically and } \\
\text { socially, would be great. It is also beneficial and concerns the natural and sanitary } \\
\text { environment. Nationally, the direct financial impact of the generalization of SWH at the } \\
\text { direct city level is around } \$ 15 \text { million. The generalization of solar water heaters in } \\
\text { Morocco will reduce the national energy bill by } 1.3 \% \text {. }\end{array}$} \\
\hline Accepted: 16 November 2021 & \\
\hline Published: 21 December 2021 & \\
\hline DOI: 10.32996/jefas.2021.3.2.22 & \\
\hline KEYWORDS & \\
\hline $\begin{array}{l}\text { Renewable Energy, Economy, } \\
\text { Impact Assessment, Solar water } \\
\text { heaters, Morocco. }\end{array}$ & \\
\hline
\end{tabular}

\section{Introduction}

In 2015, 175 Parties (174 states and the European Union) signed the agreement to decrease greenhouse gas emissions, especially in industrial countries. It is important to mention that each country involved in the negotiations on climate change must present the so-called "Nationally Determined Contributions (NDCs)"; communication on the situation of the impact of climate change. In many of these countries, solid fuels are still the dominant primary energy source, which is relatively carbon-intensive and produces local air pollution and smog. For instance, even the sun shines all day, from sunrise to sunset, for about 10 hours in Morocco. However, the use of renewable energy is still low. Faced with this situation, the question of RE's absence does not fail to arise. Especially for a country importing almost all of its energy.

The major objective of the Paris agreement is to limit global warming to $2 \mathrm{C}$. The downward trend in the current level of Greenhouse Gas (GHG) emissions is the mandatory changeover. To do so, the substitution of fossil fuels to clean energies is considered the appropriate solution. To translate this solution into operational action, the UNFCCC has implemented the Kyoto Protocol. Through the CDM (Clean Development Mechanisms), the latter encourages the financing of the implementation of economic and social development projects with a clean energy component. Needless to say, in this context, SWHs could be among the avenues to explore. Indeed, they provide hot water for domestic or industrial use without contributing to fossil fuels. Their generalization at the scale of the city of Marrakech could be in this perspective the origin of a profit today neglected.

\section{Literature Review}

Various studies were conducted in several regions to assess the economic, social, and environment of renewable energy. Theoretically speaking, RW has a good reputation, and various countries widely promote them compared to a conventional source of energy. Internationally, the market for SWH has expanded significantly during the last decade (Govinda et al., 2011). It is important to stress that the cost of solar energy is higher than the cost of fossil fuels, but it is less costly than electricity (Saxena et al., 2011). The solar energy cost is calculated using the following formula:

$$
\text { solar energy cost }=\partial \frac{\text { solar system costs during the lifetime }}{(\text { total energy gain during the lifetime }) .(\text { solar heating fraction })}
$$

Copyright: (C) 2021 the Author(s). This article is an open access article distributed under the terms and conditions of the Creative Commons Attribution (CC-BY) 4.0 license (https://creativecommons.org/licenses/by/4.0/). Published by Al-Kindi Centre for Research and Development, London, United Kingdom. 
Countries like sub-Saharan countries, Morocco, Algeria, India, etc., have a great potential for sunshine and the good solar insolation that assists solar energy investments. However, when we look at their trade balance, we find a shocking over-dependence on fossil fuels. For instance, the energy dependency rate rose from $98 \%$ in 2008 to around 93\%, which is still far from the world average (leseco, 2019). Numerous developing countries are looking at renewable energy as an efficient investment. Investment in solar energy is encouraged as the merits include: pollution-free environment, free renewable and energy source, high reliability, and low maintenance cost (Okoro et al., 2004).

Morocco will produce 1.2 GW (1.7 million $\mathrm{m}^{2}$ ) from solar water heating by 2020 (source: IEA). Renewable Power Targets for Share of Electricity Generation in Morocco are $52 \%$ by 2030 and $100 \%$ by $2050 \%$.

\section{Methodology}

Succinctly, the methodology of the surplus evaluation approach implemented was structured around the following five stages:

1- Identification of hot water consumer sectors for domestic or industrial purposes;

2- Identification of the public and private partners (PPP) involved in the research study;

3- Collection and study of available documentation;

4- Setting of evaluation assumptions;

5- Finalization of these hypotheses by field surveys.

To evaluate the economic impact of the generalization of SWH in Marrakech, we have focused our analysis on three main actors: households, Tourism, and private and public institutions.

The diagram below highlights the genesis structure of the economic surplus that has now been lost due to the lack of generalization of SWH. Five levels stand out: State, Environment, Households, Health, Employment, especially young promoters.

\subsection{State}

If the SWHs are generalized, again in the import of fossil energy not used is certain (Milton et al., 2005). Reinvented for economic and social development purposes, the impact on GDP - an indicator of the country's wealth - would certainly be improved.

\subsection{Environment}

The generalization of the SWH reduces the emission of GHG and consequently attenuates the harmful effects of climate change (Greening Benjamin, 2014). The moment they are certified in CERs, Emission Reduction Units will generate income. Invests, economic multipliers would only be more efficient. The effect on GDP is certainly beneficial.

\subsection{Households}

All households receiving an SWH will see their monthly energy bills decrease by at least a quarter (Kakaza, M. et al., 2015). significant positive effects will result:

- Direct effects:

- Indirect effect:

- Improved household income.

- $\quad$ Stimulation of demand following the improvement of income.

- $\quad$ Security and simplicity of SWH installation.

- Increased efficiency of the economic multiplier, whose impact is the improvement of GDP.

\subsection{Health}

The generalization of the SWH avoids burning fossil fuels (coal, oil, gas, and firewood) to produce energy in other forms. The immediate result is the reduction of atmospheric pollution, whose impact emerges in the following effects 


\begin{tabular}{|l|l|}
\hline Direct effects & Indirect effects \\
\hline $\begin{array}{l}\text { Reduction of respiratory diseases, sensitivity, and } \\
\text { others... }\end{array}$ & $\begin{array}{l}\text { Gains in favour of public spending stimulate the } \\
\text { economic multiplier whose impact is positive on the } \\
\text { GDP }\end{array}$ \\
\cline { 1 - 1 } Reduction of expenses related to these diseases. \\
\cline { 1 - 2 } $\begin{array}{l}\text { Elimination of fatal accidents due mainly to the gas } \\
\text { water heater. Whole families have been the victims. }\end{array}$
\end{tabular}

\subsection{Youth Employment}

The population of young graduates in Morocco, both those in basic higher education and the professional, has taken on significant dimensions today and will be more so shortly. Unemployment at their level has also reached alarming proportions (statista, 2020). Usually coming from low-income families and the middle class, poverty will affect them harder if solutions are not implemented to insert them into working life

Since it is a neuralgic and strategic population, particular attention should be given to it, especially since it has received university or professional training ranging from 2 years to 6 years after the baccalaureate. It has great assets to self-insert into the world of employment. In this context, the generalization of SWH is an opportunity not to be missed:

- The technique of SWH is simple, and the technological component it requires is rudimentary. Consisting mainly of the cutting and welding of sheet metal, our young graduates are within reach, especially those of professional I training. Generalized SWH may generate the following effects:

\begin{tabular}{|c|c|}
\hline Direct effects & Indirect effects \\
\hline $\begin{array}{l}\text { Creation of the small and medium industrial } \\
\text { enterprise. }\end{array}$ & \multirow[t]{3}{*}{$\begin{array}{l}\text { The economic multiplier will be triggered fo } \\
\text { stimulating demand, taxation, etc. ... whose } \\
\text { impact on GDP is obvious. }\end{array}$} \\
\hline $\begin{array}{l}\text { Creation of the small and medium logistics } \\
\text { company including marketing, transport, } \\
\text { packaging, setting up } \mathrm{SWH} \text {, after-sales service... }\end{array}$ & \\
\hline Self-integration of young graduates. & \\
\hline
\end{tabular}

The diagram below highlights the genesis structure of the economic surplus that has now been lost due to the lack of generalization of SWH. Five levels stand out: 


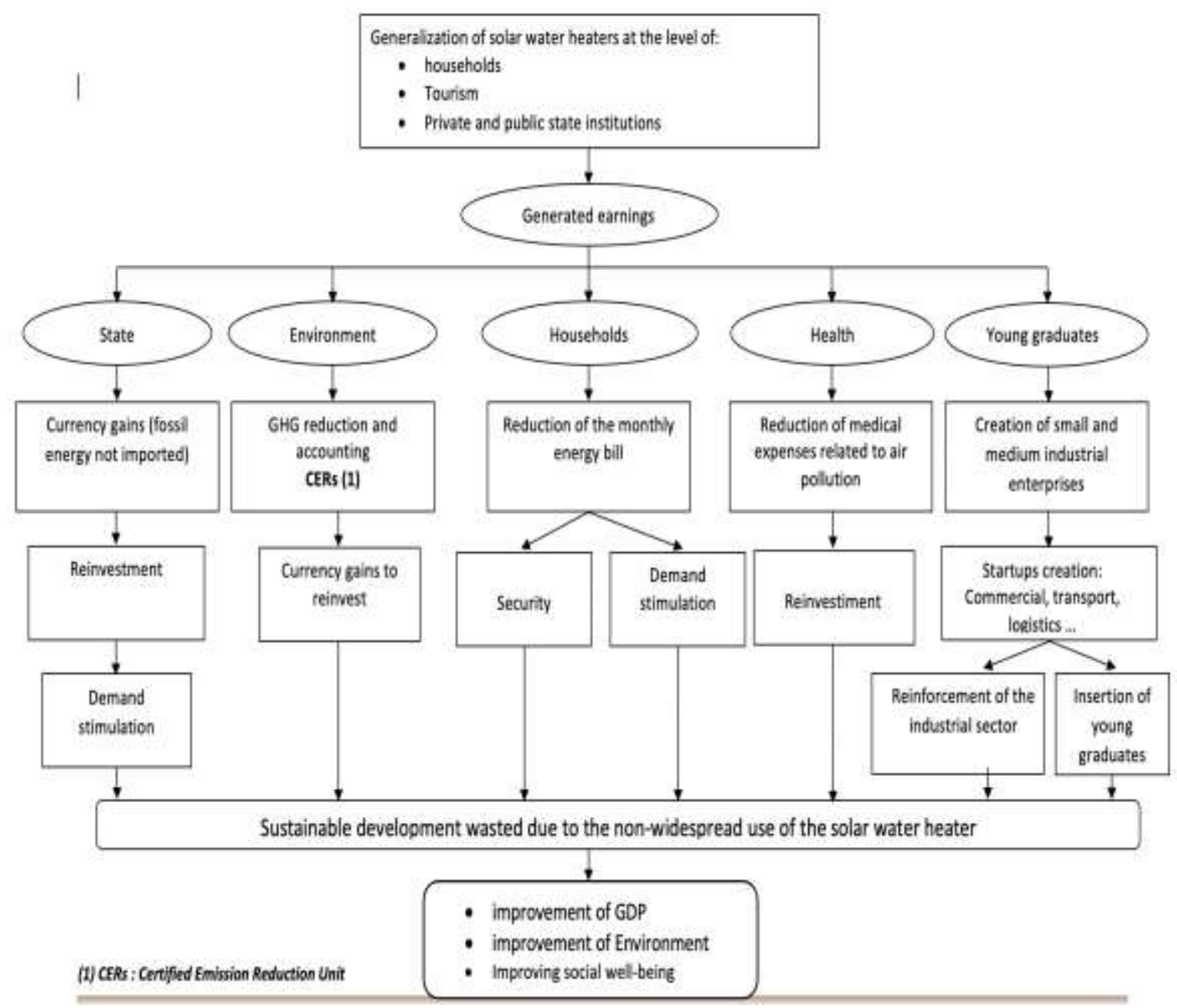

\section{Results and Discussion}

Taking as a basis the diagram presented above, materializing the tree of direct and indirect effects that could be created following the generalization of SWH on the one hand; and assumptions retained after being verified by field surveys on the other hand. Thus, in the situation where the existing potential of habitat in Marrakech is equipped totally in SWH, the economic surplus which would be gained is in the following terms:

\section{a. Gain at the state level}

\begin{tabular}{|c|c|}
\hline \multicolumn{2}{|c|}{ Impact assessment at the level of state (gain from avoiding import) } \\
\hline At the level of villas & 530868 \\
\hline At the level of other types of housing & 1771746 \\
\hline At the level of tourism & 196472 \\
\hline At the level of administrations & 9960 \\
\hline Total import gain in \$ & 2509046 \\
\hline
\end{tabular}

Where solar water heaters are generalized, there is no question that they will decrease fossil energy imports. The impact on GDP - a wealth indicator for the country - would certainly be improved. Morocco will gain about 2.5 million $\$$ if SWH is generalized just in Marrakech city. 
b. Impact on Environment Impact on Environment

\begin{tabular}{|l|l|}
\hline Gain at the level of villas & 56700 \\
\hline Gain at the level of other types of housing & 189230 \\
\hline Gain at the level of tourism & 20984 \\
\hline Gain at the level of administrations & 1064 \\
\hline The total gain in \$ & $\mathbf{2 6 7 \mathbf { 9 7 8 }}$ \\
\hline
\end{tabular}

The widespread use of the SWH lowers GHG emissions and thus alleviates the harmful effects of climate change.

\section{c. Impact on households}

\begin{tabular}{|l|l|}
\hline Gain in income at the level of households "villa zones." & 14000 \\
\hline Total number of households & 151200000 \\
\hline Total consumption of households "villa areas" in KWH & 7000 \\
\hline Number of households concerned (50\%) & 75600000 \\
\hline Total consumption of the households concerned & $25 \%$ \\
\hline The percentage of gain following the installation of an SWH & 1 \\
\hline The unit price of a kWh in DH & $\mathbf{1 8 9 0 0 0 0}$ \\
\hline Direct gain on revenue in \$ & $\mathbf{8 9 0 0}$ \\
\hline
\end{tabular}

\begin{tabular}{|l|l|}
\hline Income gain at household level "other types of housing." \\
\hline Total number of households & 219020 \\
\hline Total household consumption excluding villas in kWh & 315388800 \\
\hline Number of households concerned & 175216 \\
\hline The percentage of gain following the installation of an SWH & $25 \%$ \\
\hline The percentage of gain following the installation of an SWH & 63077760 \\
\hline The unit price of a kWh in DH & 1 \\
\hline Direct gain on income in \$ & $\mathbf{6 ~ 3 0 7 ~ 7 7 6 ~}$ \\
\hline
\end{tabular}

Houses receiving solar water heaters will see their monthly energy bills dropped by a quarter at least. The generalization of this energy source would certainly improve the household's revenue, boost demand and ensure safety. Generalizing SWH at the household level would be around 8 million \$. 
d. The impact on the tourism sector

\begin{tabular}{|l|l|}
\hline Gain in tourism & 6700000 \\
\hline Annual nights & 80 \\
\hline Average consumption per night in L / 24h (according to the survey) & 536000000 \\
\hline Total water consumption in L & 536000 \\
\hline Total water consumption in $\mathrm{m}^{3}$ & 52,2 \\
\hline $\mathrm{KWH} / \mathrm{m}^{3}$ conversion rate & 27979200 \\
\hline Electric power consumption & 6994800 \\
\hline The gain following the installation of SWH 25\% (KWH) (according to the survey) & $6994800 \mathrm{DH}$ \\
\hline The price 1KW = 1DH (MDH) & $\mathbf{6 9 9} \mathbf{4 8 0} \mathbf{\$}$ \\
\hline Gains following the installation of SWH in \$ & \\
\hline
\end{tabular}

e. The impact on public administrations

\begin{tabular}{|l|l|}
\hline Gain in administrations & 1412 \\
\hline Notal consumption (RADEEMA) & 35459394 \\
\hline Average consumption & 25113 \\
\hline The gain following the installation of SWH 1\% of the invoice (KWH) & 354594 \\
\hline The price 1KW = 1DH (MDH) & 354594 \\
\hline Gains following the installation of SWH in \$ & $\mathbf{3 5 4 5 9}$ \\
\hline
\end{tabular}

f. The gain in job creation and wealth

\begin{tabular}{|l|l|}
\hline Number of SWT to be installed & 7000 \\
\hline Villas & 175200 \\
\hline Other types of housing & 30000 \\
\hline Tourism level & 1400 \\
\hline Administrations & 213600 \\
\hline Total number of SWT to be installed & 500 \\
\hline The unit price of an SWH in \$ & $\mathbf{1 0 7}$ million \$ \\
\hline Revenue & 10 million \$ \\
\hline On the horizon of 10 years, the annual turnover & 10 \\
\hline The number of necessary companies (with a million \$ of revenue per company) & $\mathbf{1 0 0}$ \\
\hline The number of jobs created (If each company employs $\mathbf{1 0}$ positions) & $\mathbf{2 0}$ \\
\hline Indirect jobs & $\mathbf{1 2 0}$ \\
\hline Number of jobs created & \\
\hline
\end{tabular}

\begin{tabular}{|l|l|}
\hline Wealth in terms of employment \\
\hline Annual turnover & 10 million \$ \\
\hline taxation $20 \%$ & 2 million \$ \\
\hline
\end{tabular}




\section{g. Summary table}

\begin{tabular}{|l|l|}
\hline Financial gain & 3394918 \\
\hline The State & 11351664 \\
\hline households & 699480 \\
\hline Tourism & 362598 \\
\hline Environment & 35459 \\
\hline Administrations & 15844119 \\
\hline Total direct gains & 63376476 \\
\hline Total indirect gains (with an economic multiplier of 4) & $\mathbf{7 9 2 2 0 5 9 5}$ \\
\hline Total gains in \$ & 100 \\
\hline Gain in employment & 20 \\
\hline Direct jobs & \\
\hline Indirect jobs & $\mathbf{2 0}$ \\
\hline
\end{tabular}

\section{Conclusion}

The main objective of this study is to analyze and quantify the impact of the generalization of solar water heaters on different levels: the economic, social, and environment. According to the results of our study, From the result of our assessment analysis, we find that generalizing solar water heaters in Marrakech will have a positive effect on the environment, national GDP, balance of payment, and household revenue. The direct financial impact of the generalization of SWH at the direct city level is around \$15 million. Reinvested at the national economy level, and by adopting a multiplier of the order 4 , the indirect impact and of the order of $\$ 60$ Million. The total economic surplus is around $\$ 75$ million; this amount represents $1.33 \%$ of the national energy bill and $0.08 \%$ of the kingdom's GDP

In other words, a dozen cities the size of Marrakech can save 13\% on the energy bill if they benefit from the generalization of SWH. In addition, the generalization of SWH will reduce the unemployment rate in Morocco as it will create more job opportunities for young graduates. At the environmental level, the generalization of $\mathrm{SWH}$ will reduce the emission of $\mathrm{CO} 2$ into the atmosphere and contribute to the reduction of global warming.

Furthermore, this research will raise public understanding of the importance of solar water heaters by knowing the different positive impacts on different levels. In addition to this, the research's overview will push for new paradigms that will be valuable for future discussion of the impacts of solar water heaters and may lead to a more in-depth investigation of it.

In terms of recommendations, the main ones that emerged, especially during the field surveys, are expressed in the following terms:

1. The need for a political will encouraging the installation of SWH instead of traditional water heaters.

2. Take advantage of microfinance to help access SWH.

3. Create a cell or a research center working with NGOs to make this project a reality.

Funding: This research received no external funding

Conflicts of Interest: The authors declare no conflict of interest. 


\section{References}

[1] Govinda, R. Timilsina, Lado K, Patrick A. (2011). A Review of Solar Energy- Markets, Economics and Policies, Policy Research Working Paper 5845, The World Bank, Development Research Group, Environment, and Energy Team, October.

[2] Saxena, A, and Gautam S. (2011). Potential and Economics of Solar Water Heating. MIT International Journal of Mechanical Engineering 2: 97-104.

[3] Conjoncture (2019). La Facture Énergétique En Hausse. www.leseco.ma | L'actulaité en continu. AcSWHsed Octobe. https://www.leseco.ma/economie/73405-conjoncture-la-facture-energetique-en- hausse.html.

[4] Okoro, O.I. and Madueme, T.C., (2004). Technical note- Solar energy investments in a developing economy, Renewable Energy, Vol. 29, pp. 1599-1610.

[5] Milton, S., and Kaufman, S., (2005). Solar Water Heating as a Climate Protection Strategy: The Role for Carbon Finance, Green Markets International, Arlington.

[6] Greening, B, and Adisa A (2014). Domestic Solar Thermal Water Heating: A Sustainable Option for the UK? Renewable Energy $63: 23-36$. https://doi.org/10.1016/j.renene.2013.07.048.

[7] Kakaza, M., and Ka F (2015). Effect of Solar Water Heating System in Reducing Household Energy Consumption. IFAC-PapersOnLine 48, no. 30: 468-72. https://doi.org/10.1016/j.ifacol.2015.12.423.

[8] Sanders, K. T., and Michael E. W. (2015). Evaluating the Energy and CO2 Emissions Impacts of Shifts in Residential Water Heating in the United States. Energy 81: 317-27. https://doi.org/10.1016/j.energy.2014.12.045.

[9] Statista. (2020) Morocco - Youth Unemployment Rate 1998-2018. https://www.statista.com/statistics/812261/youth-unemployment-rate-inmorocco/. 